\title{
Hyvästä rengistä
}

\section{huonoksi isännäksi:}

\author{
kvantifikaatioimperatiivi \\ yhdyskuntasuunnittelussa
}

Tomas Hanell

Yhteiskuntamme nojautuu enenevässä määrin numeeriseen tietoon. Tämä koskee niin julkista kuin yksityistä sektoria. Olemme tilanteessa, jossa yhteiskunnan hallinto ei enää kykene toimimaan ilman määrällisiä mittareita. Kutsun tätä riippuvuussuhdetta kvantifikaatioimperatiiviksi. Tähän on useita syitä: muun muassa hallinnon teknokratisoituminen, siirtyminen näyttöön perustuvaan hallintotapaan tai etähallinnan asteittainen yleistyminen. Jos numeerisen tiedon implisiittistä roolia päätöksenteossa ei tunnisteta, on numeroiden varaan rakennettu päätöksenteko erittäin haavoittuvainen. Artikkelin tavoitteena on valaista tätä ilmiötä yhdyskuntasuunnittelun näkökulmasta ja lyhyesti havainnollistaa asiaan liittyviä ulottuvuuksia muutaman yksinkertaisen esimerkin avulla.

\section{Johdanto}

Yhteiskunnan - ja eritoten sen hallinnon - suhde määrälliseen tietoon on tänä päivänä erittäin läheinen. Vieläpä niin läheinen, että sen olemassaoloa on yhä vaikeampi edes kyseenalaistaa (Eberstadt 1995). Olemme joutuneet tilanteeseen, jossa yhteiskunta ei enää kykene toimimaan ilman määrällistä tietoa ja numero 
on muuttunut rengistä isännäksi. Englanninkielinen usein käytetty ja tässä vapaasti käännetty sanonta "jos et pysty mittaamaan jotain [määrällisesti], et kykene sitä hallinnoimaan", kiteyttää ytimekkäästi tämän riippuvuussuhteen. Yhdyskuntasuunnittelu käytäntönä (toisin kuin osittain tieteenalana) ei ole säästynyt tältä trendiltä, vaan on päinvastoin miltei malliesimerkki kyseisestä hallintokäytännöstä.

Karkeasti ottaen tarkasteltavana on kolme osittain erillistä seikkaa: Yhtäältä (1) numeerisen mittaamisen väitetty välttämättömyys, jota tässä kutsun kvantifikaatioimperatiiviksi, toisaalta kysymys siitä, (2) mitä mitataan, eli mitataanko relevantteja asioita, ja lopuksi, (3) suoritetaanko tämä mittaaminen oikein. Tässä artikkelissa keskityn pääsääntöisesti kahteen ensimmäiseen aiheeseen.

Tämä artikkeli perustuu vuonna 2018 pitämääni Lectio Præcursoriaan, jota on sovellettu edelleen strategisen yhdyskuntasuunnittelun viitekehykseen. Koska olen tässä ottanut laajemman otteen koko mittaamisen kulttuurista, voisi artikkelia luonnehtia myös väitöstyöni päätelmien meta-analyysiksi (Hanell 2018).

Tutkimus on luonteeltaan deskriptiivinen. Sen lähtökohtana on kirjallisuuskatsaus, jonka pohjalta pyrin valaisemaan mittaamisen kulttuuria sekä siihen liittyviä tietoisia tai tiedostamattomia valintoja. Muutaman yksinkertaisen esimerkkihavainnon avulla tarkastelen kulttuurin mahdollisia seurauksia suomalaisessa yhdyskuntasuunnittelussa uppoutumatta kuitenkaan kovin hermeneuttisesti tähän erittäin laajaan aihepiiriin. Liiallisen yksinkertaistamisen uhan tietoisesti tunnistaen, käsittelen muun muassa termejä tilasto, mittaristo, mittari, indikaattori, muuttuja, luku, numero tai indeksi yhtenä ryhmänä niitä sen enempää toisistaan erottelematta.

Vaikka lähestymistapani numeeriseen tietoon ja sillä hallinnoimiseen on suhteellisen kriittinen, on syytä täsmentää, ettei määrällistämisen lisääntyminen ole automaattisesti negatiivinen kehityskulku. Oikeanlaisilla numeroilla on mahdollista saada myös hyvää aikaan, mutta tämän edellytyksenä on, että numeerisen tiedon implisiittinen rooli päätöksenteossa tunnistetaan.

\section{Määrällinen tieto yhteiskunnallisessa päätöksenteossa}

Yhteiskunnallinen aritmetiikka kehittyi voimakkaasti edellisen vuosisadan vaihteessa (Porter 1996; 2003; Hudson \& Mina 2016). Kehitystä vauhditti kansallisvaltioiden tarve kontrolloida alaistensa tekemisiä, suunnitella ja pitää kirjaa omista tekemisistään tai verrata itseään muihin kansallisvaltioihin (Desrosières 2002). Tarjolla olevan määrällisen tiedon lisääntyessä miltei eksponentiaalisesti nykyään on harvoja yhteiskunnan osa-alueita, joita ei yritetä kuvastaa määrällisen tiedon avulla. Kun kvantifikaatio ennen nykyisenkaltaisen hallintokoneiston syntyä 
nähtiin pääsääntöisesti tieteellisenä yrityksenä ymmärtää yhteiskuntaa, nähdään se nykyään tämän lisäksi mahdollisuutena ohjata ja hallita sitä.

Rose (1991) jakaa hallinnolliset indikaattorit neljään pääryhmään. Ensimmäisenä ovat numerot, jotka kuvastavat, miten poliittinen valta jakautuu ja kuka sitä saa jakaa. Vaalipiirit määrittelevät, kuka saa missäkin äänestää ja ketä, ja miten äänet jakautuivat. Tämän tyyppiset numerot ovat keskeinen osa poliittisen vallan legitimointia. Toisena ryhmänä ovat numerot, jotka poliittisen valintaprosessin ulkopuolella kytkevät hallinnon sen hallittaviin subjekteihin. Kyselytutkimukset kartoittavat kansalaisten luottamusta hallintoon ja koettavat muuntaa yksittäisten ihmisten elämän ja mielipiteet numeroiksi toimien täten lupauksena virtaviivaistaa hallinnon toimenpiteet kansalaisten arvojen ja mielipiteitten mukaisiksi. Kolmantena erittäin laajana ryhmänä ovat mittaristot, jotka analysoivat hallinnon omaa toimintaa. Näitä ovat kansan- tai valtiontalouden tilinpito, vaihtotaseet, työttömyys- tai työllisyysasteet, sosiaalietuuksien tai asuntotuen saajat, terveystilastot, ja niin edelleen. Kaikkia näitä voidaan käsitellä mittareina jotka mittaavat hallinnon onnistumista. Neljäntenä ryhmänä Rose identifioi ne mittarit, jotka ylipäätänsä mahdollistavat modernin hallinnon. Veroilmoitukset ja yritysten tilinpidot antavat hallinnolle mahdollisuuden kontrolloida kansalaisten tai yritysten taloutta. Väestötilastot kertovat hallinnolle tärkeää tietoa ei vain siitä, missä kansalaiset asuvat, vaan myös siitä, miten esimerkiksi kuntien valtionosuudet tulee laskea ja jakaa.

Määrien ilmaiseminen, etenkin tarkkojen lukujen avulla, antaa analyysille (näennäisen) objektiivisuuden leiman. Numerot ovat myös helppo keino (näennäisesti) tiivistää vaikeita asiakokonaisuuksia pieneen tilaan. Lisäksi numero on (näennäisesti) transparentti. Numerot voi toisin sanoen nähdä retorisena keinona ilmaista vaikeaselkoisia asioita ytimekkäästi ja ristiriidattomasti (Miller 2001; Davis \& al. 2012; Shore \& Wright 2015; Rieder \& Simon 2016) ja helppona keinona luoda yksinkertaistettu narratiivi (saltelli \& Giampietro 2015) edesauttamaan hallinnollisia päätöksiä ja politiikkaa. Määrällisen tiedon voittokulkua yhteiskunnallisessa päätöksenteossa selittää kuitenkin myös moni muukin seikka.

Näyttöön perustuva hallintotapa (engl. Evidence-based policy making) on noussut yhdeksi keskeiseksi hallinnon elementiksi. Tällaisessa hallintoympäristössä nimenomaan määrällinen tieto näyttää olevan erityisen tavoiteltua - oletettavasti sen otaksutun objektiivisuuden takia. Tämä numeroiden varaan rakennettu hallinto perustuu kuitenkin usein naiviin instrumentaaliseen ajatteluun, jolloin hallinto on avoin sekä tietoiselle manipulaatiolle että heikkojen metodisten tai teknisten toteutusten seurauksena - myös ennalta arvaamattomille oheisvaikutuksille (Kitchin \& al. 2015). Näyttöön perustuva hallinto- 
tapa on kopioinut sekä käsitteistönsä että sanastonsa yritysmaailman piiristä. Osittain tämän seurauksena hallinto on myös omaksunut "rahallistumisen", eli asioiden mittaamisen pääsääntöisesti rahallisissa yksiköissä (shore \& Wright 2015). Talousantropologian termistöä käyttäen, näyttöön perustuva hallintotapa näyttäisi olevan syvälle juurtunut formalistiseen yhteiskuntakäsitykseen, jossa yhteiskunta samaistetaan yksinomaan talouteen (wilk \& cliggett 2007). Kun kyetään selittämään, miten talous toimii, on tämä samanaikaisesti myös selitys siitä, miten koko yhteiskunta toimii. Ongelma ei tosin ole aivan uusi, sillä jo 1960-luvulla Yhdysvalloissa alkuunsa saanut sosiaalisten indikaattorien liike kritisoi vahvasti jo tuolloin vallalla ollutta "uutta filistealaisuutta" (Gross 1966), jossa yhteiskunnan ohjauksessa (kansan)talouden tilinpidon annettiin esittää pääroolia.

Toinen syy numeerisen tiedon voittokulkuun liittyy hallinnon asteittaiseen teknokratisoitumiseen (Sam \& Scherer 2008; Antonelli 2016). Hallinnon vastuun siirtyessä poliitikoilta "asiantuntijoille", eli erikoistuneille virkamiehille, konsulteille, tai yhdyskuntasuunnittelun kontekstissa vaikkapa suunnittelijoille, muokkautuu hallintokulttuuri vastaavanlaisella tavalla näille ammattiryhmille sopivaksi. Määrällinen tieto on selvästi asiantuntijoiden reviiriä, ja asiantuntijuutta on vaikea kritisoida ulkoapäin. Määrällistämisen teknologia vaikuttaisi lisäksi jatkuvasti syöttävän itseään, sillä teknokraattinen hallintotapa luo jatkuvasti tarvetta yhä uudelle määrälliselle tiedolle (Fishcer 1990).

Numerot mahdollistavat myös etähallinnan (Rose 1991; Hansen \& Mühlen-Schulte 2012) eli fyysisen läsnäolon välttämättömyyden vähenemisen tai jopa kokonaan poistamisen. Samalla tapaa kuin belgialainen sarjakuvapiirtäjä Hergé uskottavasti kykeni sijoittamaan sankarinsa Tintin seikkailut eri puolelle maapalloa pelkästään valokuvien ja lehtileikkeleiden avulla, kykenisi 200o-luvun maakuntasuunnittelija teoriassa laatimaan kokonaisen maakuntakaavan pelkästään numeroiden ja kartta-aineiston avulla ilman minkäänlaista tarvetta poistua omasta konttorihuoneestaan. Etäisyyden ei tosin tarvitse olla maantieteellinen. Numerot mahdollistavat kommunikaation myös eri sosiaalisten, yhteiskunnallisten tai poliittisten ryhmien välillä (Porter 1996; Espeland \& Mitchell 2008; Lehtonen \& al. 2016) juuri sen takia, että ne mielletään arvo- tai politiikkavapaiksi ja objektiivisiksi. Numerot muodostavat eri toimijoiden välisen neutraalin maaperän, jossa konflikteja ja ristiriitaisia intressejä on helpompi sovittaa yhteen, koska sopimisen reunaehdot on jo numeroiden avulla määritelty. 


\section{"Numerot puhuvat puolestaan": määrällisen tiedon otaksuttu objektiivisuus}

Yhdysvaltalainen filosofi Harry Frankfurt (1998) pohti yhtäältä valehtelijan ja toisaalta roskanpuhujan (engl. Bullshitter) määritelmiä ja eroavaisuuksia. Hänen mukaansa roskanpuhujan ja valehtelijan suurin ero on siinä, että roskanpuhuja ei välitä, ovatko hänen väitteensä totta vai ei, kun taas valehtelija välittää. Hän välittää totuudesta niin paljon, että yrittää piilottaa sen. Jälkimmäisessä tapauksessa tilasto osoittautuu yhdeksi valehtelijan parhaimmaksi yhteistyökumppaniksi. Määrällinen tieto koetaan usein objektiivisemmaksi, tarkemmaksi ja jopa luotettavammaksi kuin kaikki muunlainen tieto (Daston \& Galison 1992). Joissain piireissä se jopa mielletään ainoaksi oikeaksi tiedoksi. Hieman ilkeästi karrikoiden voisi sanoa, että nämä tahot edustavat yleensä joko niitä, joiden ymmärrys tilastollisen tiedon rajoituksista on kaikkein vähäisin, tai niitä, joilla on jotain salattavaa. Matemaattisen tilastollisen analyysin esiisä Karl Pearson kiinnitti jo yli vuosisata sitten huomiota siihen, että vaikka tilastollisen tiedon impersonaalisuus voidaan samaistaa objektiivisuuteen, on vallalla myös väärinkäsitys, että sama objektiivisuus voitaisiin samaistaa totuuteen (Porter 1996).

Mittauksen teoria tapaa jakaa mittaustavat kahteen pääluokkaan (Michell 1986; Hand 1996; Wise 1997). Esittävässä mittaamisessa (engl. Representational measurement) tietyillä mitattavilla objekteilla on joukko ominaisuuksia, joiden perusteella ne voidaan luokitella dikotomisesti tiettyyn luokkaan tai sen ulkopuolelle Tämä mittaustapa, joka on vallitseva käytäntö esimerkiksi rekisteripohjaisessa tilastoinnissa, perustuu olettamukselle, että mitattavat objektit kuvastavat taustalla olevaa todellisuutta. Yhdyskuntasuunnittelun kontekstissa voitaisiin esimerkiksi ensin määritellä, mikä on rakennus (esim. tilavuuden perusteella jolloin vaikkapa linnunpöntöt jätettäisiin tämän mittauksen ulkopuolelle) ja sen jälkeen minkä tyyppisiä ominaisuuksia sillä on (esim. koordinaatit, käyttötarkoitus, ikä, suojelustatus), minkä ansiosta eri rakennukset kyetään kätevästi tilastoimaan omiin luokkiinsa.

Operationaalisessa mittauksessa (engl. Operational measurement) sen sijaan mittauksen metodi määritellään vasta itse mittausvaiheessa, minkä seurauksena objekti määritellään vain ja ainoastaan käytetyn mittausmetodin perusteella. Samalla oletetaan, että mitattavat objektit eivät kuvasta taustalla olevaa todellisuutta ja että mitattavaa objektia ei mittauksen ulkopuolella ole edes olemassa. Yhdyskuntasuunnittelussa tätä mittausmenetelmää sovelletaan esimerkiksi saavutettavuuslaskelmia tehdessä tai vaikkapa asukkaiden palvelutyytyväisyyttä kartoitettaessa. Aluesuunnittelun kontekstissa myös esimerkiksi eri alueiden, kaupunkien tai muun tyyppisten aluekokonaisuuk- 
sien kehitysnäkymiä, kilpailukykyä, kasvupotentiaalia tai innovatiivisuutta mittaavat indeksit luovat puhtaasti virtuaalista (eli keinotekoista) maantiedettä, jolla kuitenkin voi olla erittäin merkittävä ohjausvaikutus politiikan tai yritysmaailman faktista maantiedettä koskevaan päätöksentekoon (Moisio 2018).

Vaikka harva kyseenalaistaa jälkimmäisen mittausmenetelmän subjektiivisuuden, edellisen menetelmän suhteen väitetään joskus, että se olisi luonteeltaan neutraali tai jopa objektiivinen. Tämä lienee kuitenkin harhaluulo. Kaikki tieto tuotetaan aina jostain tietystä näkökulmasta. Koska kukaan ei ole kaikkinäkevä, tarkoittaa näkökulmaisuus myös sitä, että aina jää osia näkemättä. Se, mitä mitataan, automaattisesti määrittää myös, mitä ei mitata. Samoin, miten jokin mitataan ja kenen toimesta, mitä ehdollisia ominaisuuksia luokitteluun sisällytetään, miten ominaisuuksien raja-arvot määritellään ja niin edelleen, ovat kaikki erittäin subjektiivisia valintoja (Anderson \& Fienberg 1999; Martin \& Lynch 2009). Valintoja ohjaa myös valintojen tekijän arvomaailma, ja on jopa näyttöä siitä, että yhteys ei olisi yksisuuntaisen kausaalinen (arvomaailma -> mittaus), vaan että se voisi myös olla kaksisuuntainen (Brighenti 2018).

Subjektiivisuus ei luonnollisestikaan rajaudu ainoastaan tilaston tuottajaan. Myös tilaston tulkitsija joutuu väääämättä astumaan "numeron sisään" ja näin tehdessään hän, jalostaessaan informaatiota tiedoksi, samalla muokkaa itse tilastoa (saetnan \& al. 2010). Kontekstittomat numerot ovat itsessään pääsääntöisesti mielenkiinnottomia. Numeroita esitettäessä on ne tapana ankkuroida johonkin tiettyyn kontekstiin, "merkittävästi vähentynyt" tai "huolestuttavan korkealla", antaen täten anonyymille numerolle normatiivisen tulkinnan (sam \& scherer 2008).

Vaikka tulkinnan jonkin ihmeen kautta onnistuisi neutralisoimaan täysin "objektiiviseksi" jättäen ainoastaan numeron puhumaan puolestaan, ei mittari kuitenkaan voi olla täysin politiikkavapaa tekele, vaan sen luomiseen sisältyy aina poliittisia kannanottoja, olivatpa ne sitten tietoisia tai tiedostamattomia (Ruppert \& al. 2017). Toimittamassaan alansa merkkiteoksessa The politics of numbers, yhdysvaltalaiset tutkijat William Alonso ja Paul Starr ${ }_{(1987)}$ havainnollistavat selvästi, kuinka tiedostamattoman politisoituinuneita vaikkapa väestölaskennat ja -ennusteet tai kansantalouden tilinpito on. Kansainvälisen käytännön mukaan Suomessa kotitalouksien itselleen tuottamien palveluiden (eli palkattoman kotityön) arvo on pääsääntöisesti jätetty kansantalouden tilinpidon ulkopuolelle. Koska kotitöitten arvo yhtä kaikki on mahdollista arvioida (36,5\% BKT:stä vuonna 2016, Tilastokeskus 2018), vaikuttaa niiden poisjättäminen tilinpidosta pitkälti poliittiselta valinnalta. Äänestysalueiden ja vaalipiirien fyysinen rajaus taas on kenties kaikkein klassisin esimerkki tietoisesta tilastojen poliittisesta ohjauksesta, mutta muita, latentimpia esimerkkejä tästä ei myöskään ole vaikea löytää. Suomalaisen yhdyskuntasuunnittelun kontekstissa esimerkiksi 
se, että uusien rakennusten kasvihuonekaasupäästöjä arvioidaan, kun taas niiden rakentamisesta aiheutuvia päästöjä - jotka voivat olla merkittävämmät kuin käytöstä aiheutuvat (Heinonen \& al. 2012; ibn-Mohammed \& al. 2013) - ei tänä päivänä vielä arvioida, lienee suurilta osin poliittinen valinta.

\section{Indikaattorien diskursiivisuus ja ohjausvaikutus}

Sikäli kun mittaaminen on arvoperusteinen valinta tai jopa poliittinen teko, myös mittari itsessään kykenee tekemään politiikkaa ja luomaan arvopohjaa. Hämmästyttävän laajaa keskustelua herättänyt ranskalaisen Stiglitz-komitean raportti "Report by the Commission on the Measurement of Economic Performance and Social Progress" (stiglitz \& al. 2009) otti vahvasti kantaa ilmiöön, jossa yhteiskunnan käyttämillä keskeisillä tilastollisilla indikaattoreilla on taipumus ajan myötä hiljalleen alkaa muokkaamaan tavoiteltuja päämääriä. Tämä tapahtuu siksi, että jos poliittisten tavoitteiden asettamiseen käytettyjen indikaattoreiden paletti merkittävästi laiminlyö tiettyjä yhteiskunnallisesti tärkeiksi miellettyjä seikkoja, tapaavat nämä näkökohdat pitkällä aikavälillä pudota pois politiikan tavoitteiden luettelosta. Asiat, joita mitataan, muuttuvat huomaamatta yhteiskunnan tavoitteiksi, ja lopulta ainoiksi saavutetuiksi seikoiksi. Tilasto tai mittari muuttaa näin huomaamattomasti muotoaan objektista subjektiksi. Englanninkielinen sanonta "mittaamme sitä, mitä arvostamme" muuttuukin huomaamatta muotoon "arvostamme sitä, mitä mittaamme" (kirjoittajan vapaat käännökset ${ }^{1}$ ). Kyse on yhtäältä siitä, mitä yhteiskunta haluaa mitata, ja toisaalta, mitä se kykenee mittaamaan. Haasteellisinta on, jos mittaamisessa aina painottuu ainoastaan se, mitä (otaksuttavasti) kyetään mittaamaan, sen sijaan mitä oikeasti olisi syytä mitata (Sieber 1981).

Useimmat politiikan ja hallinnon hankkeet vakuuttavat retorisella tasolla tähtäävänsä johonkin tiettyyn lopputulokseen, mutta arvioivat käytännössä onnistumistaan aivan muilla mittausvälineistöillä. Hyvä esimerkki tästä on EU:n puitteissa toteutettavat alueelliset rakennepoliittiset ohjelmat ja strategiat, jotka nielevät noin kolmasosan EU:n budjetista. Nämä väittävät nimenomaisesti tähtäävänsä köyhyyden ja sosiaalisen syrjäytymisen vähentämiseen tai kansalaisten elämänlaadun lisäämiseen. Viralliset mittarit, joita käytetään EU 2020 -strategian seurantaan tai EU:n rakennerahastojen tukikelpoisuuden määrittelemiseen, eivät kuitenkaan kykene tilastollisesti huomioimaan sosiaalista yhteenkuuluvuutta tai kansalaisten elämänlaatua (sánchez-Domínguez \& Martos 2016; Hanell 2018). Tämä ei johdu siitä, että käytetyt viralliset seurantamittarit olisivat

1 "We measure what we treasure" vs. "we treasure what we measure". 
itsessään huonolaatuisia, vaan siitä, etteivät ne keskity retoristen tavoitteiden näkökulmasta olennaiseen, vaan mittaavat jotain aivan muuta.

Ilmiötä vauhdittaa joidenkin indikaattorien asteittainen muuttuminen eristetyistä tilastollisista mittareista omaa elämäänsä eläviksi itsenäisiksi toimijoiksi, eli diskursiivisiksi elementeiksi (Ortega-Cerdà 2005; Carlon \& al. 2006; Löwenheim 2008; verloo \& al. 2009). Tietty tilastollinen mittari voi yhteiskunnallisessa keskustelussa saada ikään kuin itsenäisen aseman ja käytännössä myös poliittista valtaa. Ei liene liioiteltua väittää, että kevään 2019 eduskuntavaalien jälkeen maan vaikutusvaltaisin poliittinen toimija näyttäisi olevan indikaattori nimeltä "Työllisyysaste" riippumatta siitä, mikä puolue tai kuka yksittäinen kandidaatti sai eniten ääniä.

Yhdyskuntasuunnittelun näkökulmasta hyvä esimerkki diskursiivisen indikaattorin ristiriitaisesta ohjausvaikutuksesta on kasvihuonekaasupäästöt, jotka yleisimmin ilmaistaan hiilidioksidiekvivalentteina. Mittari elää yhteiskunnallisen päätöksenteon puitteissa varsin itsenäistä elämää irrotettuna kaikesta päivänpolitiikan tai poliittisen arvomaailman kentästä. Harvasta yhdyskuntasuunnittelun alaa hipovassa taustadokumentista puuttuu pakollinen maininta kasvihuonekaasupäästöjen alentamisen välttämättömyydestä.

Suomessa, kuten myös EU:n piirissä, näistä päästöistä keskustellaan kuitenkin pääsääntöisesti tuotantoperusteisesti, ja vasta aivan viime aikoina on ryhdytty käsittelemään niitä myös kulutusperusteisina seikkoina (vrt. esim. ottelin \& al. 2019). Tuotantoperusteinen mittaus voi kuitenkin ohjata toimiamme osittain - tai jopa kokonaan - haitalliseen suuntaan. Esimerkkinä tästä käy vaikkapa se, että Suomen valtion alueella henkilöliikenteen kasvihuonekaasupäästöjä voitaisiin tilastollisesti huomattavasti alentaa siirtymällä enenevässä määrin sähkökäyttöisiin autoihin, edellyttäen, että niiden tarvitsema sähkö kyettäisiin tuottamaan vähäpäästöisesti. Tämä mittaustapa ei kuitenkaan lainkaan huomioi energiankulutusta, ja siitä aiheutuvia kasvihuonekaasupäästöjä, joita itse sähköauton valmistaminen ja kuljettaminen Suomeen aikaansaavat. Nämä päästöt rasittavat auton tuotantomaan, vaikkapa Kiinan, tilejä ja voivat joissain tilanteissa (Hawkins \& al. 2013; Lehmann \& al. 2018) olla suurempia kuin päästösäästöt, jotka sähköautoihin siirtyminen Suomessa aikaansaavat. Samoin muut negatiiviset ympäristövaikutukset, kuten esimerkiksi ekotoksisuus (vargas \& al, 2019), tiliöidään valmistusmaahan.

Koska ilmaston lämpeneminen kuitenkin on globaali kysymys ja siten maapallon kansallisvaltioiden keskeinen nollasummapeli, on nykyisenkaltaisella kasvihuonekaasupäästöjen tilastollisella määrittelyllä erittäin kauaskantoisia käytännön vaikutuksia. Tämä niin sanotun hiilivuodon (engl. Carbon leakage) mittauksen ongelma toistuu tosin osittain monissa globaaleissa kestävän 
kehityksen mittareissa, kuten vaikkapa Aidon kehityksen indikaattorissa (GPI; Genuine Progress Indicator) tai Ympäristön suoriutuvuuden indikaattorissa (EPI; Environmental Performance Index) (Hoffrén 2018).

Monet tätä nykyä yhteiskunnallisessa (ml. yhdyskuntasuunnittelun) käytössä olevat käsitteet ovat saaneet alkunsa hallinnon tai politiikan piirissä ja ovat usein lisäksi ulkomaista tuontitavaraa. Tyypillisesti uudet politiikka- tai policy-käsitteet ovat ensi alkuun varsin epämääräisiä, mutta ajan myötä on ilmennyt tarve niitten tarkemmalle määrittelylle. Hyviä esimerkkejä tällaisesta prosessista ovat esimerkiksi kestävä kehitys, alueellinen yhteenkuuluvuus (engl. Territorial Cohesion), tai älykkään erikoistumisen strategiat (engl. Smart Specialisation Strategies). Koska yhteiskunta elää kvantifikaatioimperatiivin ikeen alla, ilmenee tässä yhteydessä ennemmin tai myöhemmin myös tarve käsitteiden määrällistämiseen. Tämän tyyppinen tilastollinen operationalisointi toimii monissa tapauksissa myös tietyn käsitteen määrittelijänä, tarkentajana ja rajoittajana. Usein juuri yksimielisyys jonkin tietyn käsitteen mittausmenetelmästä toimii sen sisällöllisenä vakauttajana (Armstrong \& caldwell 2004). Tämän tapahtuessa tietyn mittauksen puhtaasti tekniset valinnat vaikuttavat suoraan itse käsitteen sisältöön. Eurooppalaisen strategisen aluesuunnittelun piirissä esimerkiksi käsitteelle alueellinen konvergenssi (engl. Regional convergence) kävi juuri näin. Tänä päivänä useimmat tahot ovat yksimielisiä siitä, että alueellista konvergenssia mitataan joko sigma- tai beta-konvergenssitekniikoiden avulla ja lisäksi siitä että näihin laskelmiin syötetty muuttuja pääsääntöisesti on bruttokansantuote per asukas. Ensin keksittiin konsepti, sen jälkeen määriteltiin konsepti tilastollisesti, ja nyt tilasto ja sen laskentamenetelmä yksinvaltaisesti hallinnoivat konseptia.

\section{Suomalaisen yhdyskuntasuunnittelun} kaksi teemaa ja näitä yhdistävä silta

Yhdyskuntasuunnittelulla - jonka tässä miellän laajasti strategiseksi yhdyskuntasuunnitteluksi ennemmin kuin käytännön maankäytön suunnitteluksi-on vahvat siteet määrälliseen tietoon. Tämä selittyy osin sillä, että karttapohjainen tieto on hyvin pitkään muodostanut keskeisen osan maankäytön suunnittelua, ei vähiten siksi, että kartta on myös juridis-hallinnollinen dokumentti. Kartan dikotomisesta määrällisestä tiedosta, eli siitä, kuuluuko jokin tietty alue vai ei johonkin tiettyyn luokkaan (viheralue tai ei, rakennusoikeus tai ei, jne.), on ollut helppo ponnahtaa myös "perinteiseen" määrälliseen tietoon ja sen myötä myös tilastointiin. Alkuun siirtymä liittyi yksinkertaisesti karttojen eri alueluokkien summeeraukseen, mutta käytännön yhdyskuntasuunnittelussa numeerisen tiedon käsittely on tänä päivänä viety huomattavasti pidemmälle. 
Esimerkiksi erilaiset vaikutusten arvioinnit, ennusteet tai mallinnukset nojaavat yhdyskuntasuunnittelussa vahvasti määrälliseen tietoon.

Suomalaisessa yhdyskuntasuunnittelussa käytettyjen mittareiden kirjo on historiallisista - ja osittain myös juridisista - syistä varsin laaja, koska maankäyttö ja aluesuunnittelu ovat luonteeltaan erittäin holistista toimintaa. Tästä riippumatta voi käytännön strategisessa yhdyskuntasuunnittelussa kuitenkin erottaa kaksi ylitse muiden ulottuvaa kattoteemaa: ympäristö ja talous. Nämä kaksi aihetta kehystävät niin vahvasti suomalaisen yhdyskuntasuunnittelun diskurssia, että monet muut yhteiskunnallisesti tärkeiksi mielletyt seikat on selvästi jätetty taka-alalle. Esimerkiksi hyvinvoinnin, tai vaikkapa sosiaalisen yhteenkuuluvuuden, otaksutaan implisiittisesti toteutuvan ikään kuin kausaalisen prosessin automaattisena seurauksena, jos vain talous- ja ympäristöasiat saadaan hallintaan.

Sekä talous- että ympäristödiskurssia yhdistää imperatiivisuus. Ekologisuuden huomioonottamisen välttämättömyyttä on vaikea olemassa olevan tieteen valossa kiistää, mutta sama ei päde talouden vastaavaan. Talouskasvun välttämättömyyttä motivoidaan implisiittisesti seuraavanlaisella kausaalisella ketjulla: talouskasvu $\rightarrow$ julkistalouden tasapaino $\rightarrow$ hyvinvointivaltio $\rightarrow$ ihmisen hyvinvointi. Tämä kausaalisuus ei kuitenkaan kestä kriittistä tarkastelua, koska muitakin vaihtoehtoja hyvinvoinnin saavuttamiseen on ainakin teoriassa mahdollisuus identifioida, jos hyvinvoinnin saavuttaminen ylipäänsä on edes tavoitteena.

Kuten yllä mainittiin, erittäin suuri osa ympäristöön liittyvistä näkökohdista on käytännössä typistetty yhteen ainoaan mittariin, eli ilmakehän kasvihuonekaasupäästöihin, ja erityisesti hilidioksidipäästöihin. Monet seikat, jotka eivät suoranaisesti liity päästöjen vähentämiseen, rinnastetaan yhteiskunnallisessa keskustelussa jollain tapaa siihen. Hyvänä esimerkkinä tästä on vaikkapa keskustelu uusiutuvista kotimaisista energianlähteistä, jotka esimerkiksi perustuessaan biopolttoaineisiin edistävät päästöjen vähentämistä korkeintaan marginaalisesti. Vastaava epälooginen kytkös tehdään myös luonnon monimuotoisuuden ja hiilineutraaliuden välillä, vaikka näillä kahdella ei välttämättä tarvitse olla suurtakaan yhteyttä toisiinsa.

Vaikka talouden tehokkuutta ja kasvua mittaavien mittareiden kirjo on jonkin verran laajempi, ovat yhtä kaikki kansantuote ja työllisyysaste yksittäisinä mittareina silti erittäin keskeisessä asemassa: kansantuote yleisenä talouskasvun kuvaajana, ja työllisyysaste hyvinvointivaltion ainoana mahdollistajana.

Talouskasvu ja vähäpäästöisyys nähtiin pitkään toistensa vastakohtina, eli joko/tai dikotomiana. Noin 1990-luvun puolivälistä lähtien onnistuttiin kuitenkin diskurssitasolla poistamaan suuri osa tästä vastakkainasettelusta 


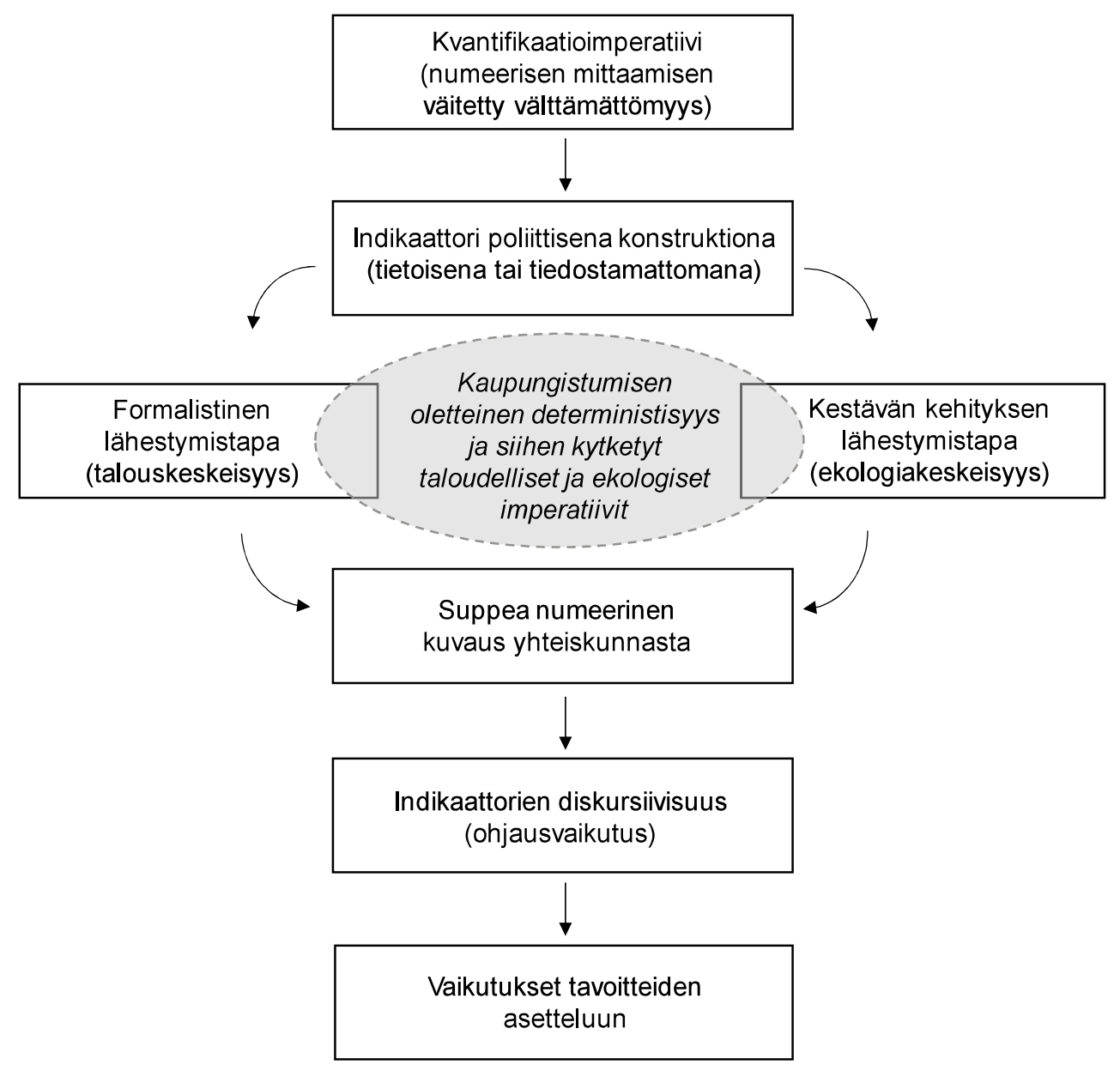

Kuvı 1 Suomalainen yhdyskuntasuunnitteludiskurssi 2010-luvulla ja siihen kytkeytyvä mittausongelma. Lähde: kirjoittajan oma visualisointi.

yhdistämällä molemmat kaupungistumiseen. Yhtäältä kaupungistuminen nähdään tänä päivänä elinkeinoelämän kehityksen ja kilpailukyvyn kannalta välttämättömyytenä, toisaalta se myös mielletään miltei ainoaksi mahdollisuudeksi saavuttaa ekologinen tasapaino ja hillitä ilmastonmuutosta. Kaupungistumista kuvaavia mittareita - kuten urbanisaatioastetta, taajama-astetta tai erinäisiä morfologisia kaupunkiseutuja kuvaavia mittareita - löytyykin siksi paljolti juuri maankäytönsuunnittelua ohjaavista strategioista ja esiselvityksistä. Kuviossa 1 yritän tiivistää yllä ja edellisissä kappaleissa esiin nostetut näkökohdat yksinkertaistettuun analyyttiseen kehikkoon. 
Diskurssitasolla kausaalinen väittämäketju kulkeekin nyt näin: kaupungistuminen $\rightarrow$ vähähiilinen/ekologisesti kestävä talouskasvu $\rightarrow$ julkistalouden tasapaino $\rightarrow$ hyvinvointivaltio $\rightarrow$ ihmisen hyvinvointi.

Kaupungistumista käsitellään usein diskurssitasolla täysin epäpoliittisena ilmiönä, joka rinnastetaan kritiikittömästi luonnonlakiin. Urbanisaatiosta annetaan kuva vääjäämättömästi etenevänä prosessina, joka on täysin irtaantunut poliittisesta toiminnasta tai muista yhteiskunnallisista päätöksistä tai arvomaailmoista. Tällaisesta näkökulmasta katsottuna kaupungistuminen sekä ympäristön että talouskasvun kannalta vaikuttaisi itse asiassa ainoalta mahdolliselta ratkaisulta, mitä se ei tietenkään voi olla.

Hyvänä esimerkkinä tämän typpisestä argumentoinnista on syksyllä 2018 julkistettu "Raideliikenne mahdollistaa" -selvitys (Rajala \& al. 2018), joka sai Suomessa huomattavan paljon mediahuomiota muun muassa sen vuoksi, että silloinen Liikenne- ja viestintäministeri otti henkilökohtaisesti osaa selvityksen julkistamistilaisuuteen, lausuen siellä, että "[n]opeita raideyhteyksiä tarvitaan Suomessa työssäkäyntialueiden laajentamiseksi, talouskasvun edistämiseksi ja ilmastonmuutoksen hillitsemiseksi" (Turun Sanomat 11.9.2018). Vaikka kyseinen selvitys on osa paljon laajempaa taustatyötä, toimii se hyvänä esimerkkinä siitä, miten numeerinen tieto on (tiedostamatta tai tietoisesti) valjastettu poliittisen päätöksenteon tueksi. Selvitys on 44-sivuinen, joista 7 sivua on kansikuvaa, otsikkosivuja, esilauseita tai lähdeluetteloita, jättäen 37 sivua itse asiasisällölle. Määrällistämisen imperatiivia kuvastaa se, että näistä 37 sivusta 24 (tai kaksi kolmasosaa) perustuu jossain muodossa määrälliselle argumentoinnille, ja käytettyjen mittareiden diskursiivisuutta se, että valtaosa numeerisesta tiedosta pohjautuu argumenttitasolla joko talouskasvun mahdollistamiseen tai päästötavoitteisiin pääsemiseen sekä näitä molempia mahdollistavaan kaupungistumiseen.

\section{Loppusanat}

Elämme nyt aikaa, jota hallitsee määrällisen mittaamisen imperatiivisuus ja tilastojen hegemonia. Lisäksi monet keskeisimmät yhteiskunnalliset mittarimme on pääsääntöisesti ilmaistu euromääräisinä - jos ei suoranaisesti, niin ainakin toissijaisina johdannaisina, kuten tuloina, voittoina, veroina, tulonsiirtoina, tukina tai investointeina. Miltei jokainen yhteiskunnan osa-alue rinnastetaan jossain vaiheessa ja jossain muodossa yhteismitallisesti talouteen. Toisaalta suuri osa keskeisimmistä mittareistamme liittyvät samanaikaisesti myös kestävään kehitykseen ja ekologisuuteen. Vaikka luonnonympäristön yhteismitallistamiseen rahallisissa yksiköissä on olemassa suuri joukko teknisiä apuvälineitä (vrt. Garrod \& Willis 1999), on kaupungistuminen megatrendinä menestyksekkäästi onnistunut luomaan yhteisen kiintopinnan näitten kahden välillä. 
Olemme siis tilanteessa, jossa väitetään, että kaikkea on "pakko" mitata määrällisesti, mutta lisäksi ensisijaisesti joko euromääräisesti tai hiilidioksidiekvivalenttien linssien läpi. Keskeisimmät mittarimme ovat lisäksi vaarassa alkaa itsenäisesti ohjaamaan toimiamme, eli muuttua passiivisista objekteista aktiivisiksi subjekteiksi. Jos väite, että mitä yhteiskunnassa mitataan, siihen myös pyritään, oikeasti pitää paikkansa, on asia varsin huolestuttava. Koska tarjolla olevan numeerisen tiedon määrä päivä päivältä kasvaa voimakkaasti, tähän olisi kiireellisesti saatava aikaan sellainen muutos, että rupeaisimme oikeasti saamaan sitä, mitä yhteiskuntana haluamme, eikä ainoastaan niitä seikkoja, mitä tänä päivänä tahdomme tai kykenemme mittaamaan.

Tällaisessa tilanteessa ammattimaisuuden ja asiantuntijuuden rooli korostunee entisestään. Barnes ja Hannah (2001) toistavat artikkelissaan vanhan vitsin: "On olemassa kahdenlaisia maantieteilijöitä - niitä, jotka osaavat laskea, ja niitä, jotka eivät osaa" (kirjoittajan vapaa käännös). Vitsi osuu myös yhdyskuntasuunnitteluun. Kvantifikaatioimperatiivi varmistaa, että jatkossa keskeisin ryhmä on vitsistä puuttuva kolmas luokka, eli suunnittelun ammattilaiset, jotka luontevasti kykenevät yhdistämään sekä määrällisen tiedonjalostuksen tekniikat että niiden laadullisen kritiikin. Erityisesti tekoälyn algoritmeihin perustuvan päätöksenteon vääjäämättömästi yleistyessä olisi tärkeää, että mallinnuksiin kyettäisiin sisällyttämään tilastotietoa, jolla oikeasti on merkitystä kansalaisten elämässä. Näin suunnittelussa itsensä isännäksi nostanut tilastotieto saataisiin kätevästi siirrettyä takaisin sille kuuluvaan rengintupaan.

KIITOKSET

Tätä tutkimusta on rahoittanut Suomen Akatemia (JustDe - Justification for agreement-based approaches in Nordic spatial planning: towards situational direct democracy?- hanke, 315772).

KIRJALLISUUS

Alonso, William \& Starr, Paul (1987). The politics of numbers. Russell Sage Foundation, New York. Anderson, Margo, \& Fienberg, Stephen E. (1999). Who counts?: The politics of census-taking in contemporary America. Russell Sage Foundation, New York.

Antonelli, Francesco (2016). Ambivalence of official statistics: some theoretical-methodological notes. International Review of Sociology, 26(3), 354-366. https://doi.org/10.1080/03906701.2016.1244924 Armstrong, David \& Caldwell, Deborah (2004). Origins of the Concept of Quality of Life in Health Care: A Rhetorical Solution to a Political Problem. Social Theory \& Health, 2004, 2, 361-371. https://doi. org/10.1057/palgrave.sth. 8700038

Barnes, Trevor J. \& Hannah, Mathew (2001). The place of numbers: histories, geographies, and theories of quantification. Environment and Planning D: Society and Space 2001, volume 19, 379-383. https://doi. org/10.1068/d19o4ed

Brighenti, Andrea M. (2018). The social life of measures: Conceptualizing measure-value environments. Theory, Culture \& Society, 35(1), 23-44. https://doi.org/10.1177/o263276416689o28

Carlon, Donna M. \& Downs, Alexis A. \& Wert-Gray, Stacia (2006). Statistics as fetishes: The case of financial performance measures and executive compensation. Organizational Research Methods, 9(4), 475-49o. https://doi.org/10.1177/1094428106291056 
Daston, Lorraine \& Galison, Peter (1992). The image of objectivity. Representations, (40), 81-128. https://doi. org $/ 10.2307 / 2928741$

Davis, Kevin E. \& Kingsbury, Benedict \& Merry, Sally Engle (2012). Indicators as a technology of global governance. Law \& Society Review, 46(1), 71-104. https://doi.org/10.1111/j.1540- $5893.2012 .00473 . \mathrm{x}$

Desrosières, Alain (2002). The politics of large numbers: A history of statistical reasoning. Harvard University Press, Harvard.

Eberstadt, Nicholas (1995). The tyranny of numbers: Mismeasurement and misrule (Vol. 528). AEI Press, Washington D.C.

Espeland, Wendy N. \& Stevens, Mitchell L. (2008). A sociology of quantification. European Journal of Sociology/ Archives Européennes de Sociologie, 49(3), 401-436. https://doi.org/10.1017/Sooo397560900015o

Fischer, Frank (1990). Technocracy and the Politics of Expertise. SAGE, Newbury Park, California

Frankfurt, Harry G. (1998). On Bullshit. The Importance of What We Care About. Cambridge University Press, Cambridge.

Garrod, Guy \& Willis, Kenneth G. (1999). Economic valuation of the environment. Edward Elgar Publishing, Cheltenham

Gross, Bertram Myron (1966). The state of the nation: Social systems accounting (Vol. 12). Tavistock Publications, Lontoo.

Hand, David J. (1996). Statistics and the theory of measurement. Journal of the Royal Statistical Society: Series A (Statistics in Society), 159(3), 445-473. https://doi.org/10.2307/2983326

Hanell, Tomas (2018). Regional Quality of Life in the EU - Comprehending the European space beyond GDP through the capability approach. Aalto University publication series. Doctoral dissertations 190/2018

Hawkins, Troy R. \& Singh, Bhawna \& Majeau-Bettez, Guillaume \& Strømman, Anders Hammer (2013). Comparative environmental life cycle assessment of conventional and electric vehicles. Journal of Industrial Ecology, 17(1), 53-64. https://doi.org/10.1111/j.1530-9290.2012.00532.x

Heinonen, Jukka \& Säynäjoki, Antti \& Kuronen, Matti \& Junnila, Seppo (2012). Are the greenhouse gas implications of new residential developments understood wrongly?. Energies, 5(8), 2874-2893. https:// doi.org/10.339o/en5082874

Hoffrén, Jukka (2018). Hyvinvointitalouden mittareiden käyttökelpoisuus päätöksenteossa. Eduskunnan tulevaisuusvaliokunnan julkaisu 8/2018. Eduskunta, Helsinki.

Hudson, Pat \& Ishizu, Mina (2016). History by numbers: An introduction to quantitative approaches. Oxford University Press, New York.

Ibn-Mohammed, Taofeeq \& Greenough, Rick \& Taylor, Simon \& Ozawa-Meida, Leticia, \& Acquaye, Adolf (2013). Operational vs. embodied emissions in buildings-A review of current trends. Energy and Buildings, 66, 232-245. https://doi.org/10.1016/j.enbuild.2013.07.026

Kitchin, Rob \& Lauriault, Tracey P. \& McArdle, Gavin (2015). Knowing and governing cities through urban indicators, city benchmarking and real-time dashboards. Regional Studies, Regional Science, 2(1), 6-28. https://doi.org/10.1080/21681376.2014.983149

Lehmann, Annekatrin \& Berger, Markus \& Finkbeiner, Matthias (2018). Life Cycle Based CO2 Emission Credits Options for Improving the Efficiency and Effectiveness of Current Tailpipe Emissions Regulation in the Automotive Industry. Journal of Industrial Ecology, 22(5), 1066-1079. https://doi.org/10.1111/jiec.1265.7. Lehtonen, Markku \& Sébastien, Léa \& Bauler, Tom (2016). The multiple roles of sustainability indicators in informational governance: between intended use and unanticipated influence. Current Opinion in Environmental Sustainability, 18, 1-9. https://doi.org/10.1016/j.cosust 2015.05.009

Löwenheim, Oded (2008). Examining the State: a Foucauldian perspective on international 'governance indicators'. Third World Quarterly, 29(2), 255-274. https://doi.org/10.1080/01436590701806814

Martin, Aryn \& Lynch, Michael (2009). Counting things and people: The practices and politics of counting Social Problems, 56(2), 243-266. https://doi.org/10.1525/sp.2009.56.2.243

Michell, Joel (1986). Measurement scales and statistics: a clash of paradigms. Psychological bulletin, 100(3), 398-407. https://doi.org/10.1037/0033-2909.100.3.398

Miller, Peter (2001). Governing by numbers: Why calculative practices matter Social Research, 68(2), 379-396.

Moisio, Sami (2018). Geopolitics of the Knowledge-Based Economy. Routledge, Lontoo. https://doi. org/10.4324/9781315742984 
Ortega-Cerdà, Miquel (2005). Sustainability indicators as discursive elements. In 6th International Conference of the European Society for Ecological Economics, Lisbon (pp. 14-17).

Ottelin, Juudit \& Ala-Mantila, Sanna \& Heinonen, Jukka \& Wiedmann, Thomas \& Clarke, Jack, \& Junnila, Seppo (2019, painossa). What can we learn from consumption-based carbon footprints at different spatial scales? Review of policy implications. Environmental Research Letters. https://doiorg/10.1088/1748-9326/ab2212.

Porter, Theodore M. (2003). Measurement, Objectivity, and Trust. Measurement: Interdisciplinary Research and Perspectives, 1(4), 241-255. https://doi.org/10.1207/S15366359MEAo104_1

Porter, Theodore M. (1996). Trust in numbers: The pursuit of objectivity in science and public life. Princeton University Press, Princeton, New Jersey. https:///doi.org/10.1515/978140o821617.

Rajala, Pasi \& Kauppinen, Eero \& Molin, Peter \& af Hällström, Anna \& Broman, Iris \& Salli, Riikka \& Salminen, Eero (2018). Raideliikenne mahdollistaa. Ramboll Finland Oy, Espoo. [viitattu 22.1.2019] 〈https://fi.ramboll.com/projektit/rfi/raideliikenne-mahdollistaa-selvitys〉

Rose, Nikolas (1991). Governing by numbers: Figuring out democracy. Accounting, organizations and society, 16(7), 673-692. https://doi.org/10.1016/0361-3682(91)900o19-B

Ruppert, Evelyn \& Isin, Engin \& Bigo, Didier (2017). Data politics. Big Data \& Society, 4(2), 1-7. https://doi. org/10.1177//20539517177177.749.

Saetnan, Ann Rudinow \& Lomell, Mork Heidi \& Hammer, Svein (2010). Introduction: By the very act of counting: The mutual construction of statistics and society. Teoksessa A. Rudinow Saetnan \& H. Mork Lomell \& S. Hammer (toim.): The Mutual Construction of Statistics and Society, s. 1-17. Routledge, Lontoo. https://doi.org/10.4324/9780203846612

Saltelli, Andrea \& Giampietro, Mario (2015). The fallacy of evidence based policy. Draft paper submitted for a special issue on FUTURES. [viitattu 16.2.2019] 〈https://arxiv.org/pdf/1607.07398>

Sam, Michael P. \& Scherer, Jay (2008). Stand up and be counted: Numerical storylines in a stadium debate. International Review for the Sociology of Sport, 43(1), 53-70. https://doi.org/10.1177/1012690208094426

Sánchez-Dominguez, Ángeles \& Martos ,Maria J. Ruiz (2016). Europe 2020 Strategy Under the Scope of Life Satisfaction (No. 16/01). Department of Economic Theory and Economic History of the University of Granada.

Shore, Cris, \& Wright, Susan (2015). Governing by numbers: Audit culture, rankings and the new world order. Social Anthropology, 23(1), 22-28. https://doi.org/10.1111/1469-8676.12098

Sieber, Sam (1981). Fatal remedies: The ironies of social intervention. Plenum Press, New York \& Lontoo. https://doi.org/10.10o7/978-1-4684-7456-5.

Stiglitz, Joseph E. \& Sen, Amartya \& Fitoussi, Jean-Paul (2009). Report by the Commission on the Measurement of Economic Performance and Social Progress. L'Institut national de la statistique \& des études économiques, Pariisi.

Tilastokeskus (2018). Kotitaloustuotannon arvo 2016. Suomen virallinen tilasto, Kansantalous 2018 Tilastokeskus, Helsinki.

Turun Sanomat 11.9.2018. Tunnin junia Turkuun ja Tampereelle pusketaan eteenpäin - Suomeen halutaan yksi iso työmarkkina-alue. Kirsi Turkki, Paikalliset.

Valtioneuvosto (2019). Pääministeri Antti Rinteen hallituksen ohjelma 6.6.2019 osallistava ja osaava Suomi - sosiaalisesti, taloudellisesti ja ekologisesti kestävä yhteiskunta. Valtioneuvoston julkaisuja 2019:23. Valtioneuvosto, Helsinki. [viitattu 1.7.2019] 〈http://julkaisut.valtioneuvosto.fi/handle/10024/161662〉.

Vargas, Jorge Enrique Velandia \& Falco, Daniela Godoy \& da Silva Walter, Arnaldo César \& Cavaliero, Carla Kazue Nakao \& Seabra, Joaquim Eugênio Abel (2019). Life cycle assessment of electric vehicles and buses in Brazil: effects of local manufacturing, mass reduction, and energy consumption evolution. The International Journal of Life Cycle Assessment, 1-20.

Verloo, Mieke \& Van der Vleuten, Anna (2009). The discursive logic of ranking and benchmarking Understanding gender equality me§asures in the European Union. Teoksessa E. Lombardo, P. Meier \& M. Verloo (toim.): The Discursive Politics of Gender Equality. Stretching, bending and policymaking, $s$. 189-205. Routledge, Lontoo.

Wilk, Richard R., \& Cliggett, Lisa C. (2007). Economies and cultures: foundations of economic anthropology. Second edition. Westview Press, Hatchett.

Wise, Norton M. (Toim.). (1997). The values of precision. Princeton University Press, New Jersey. 